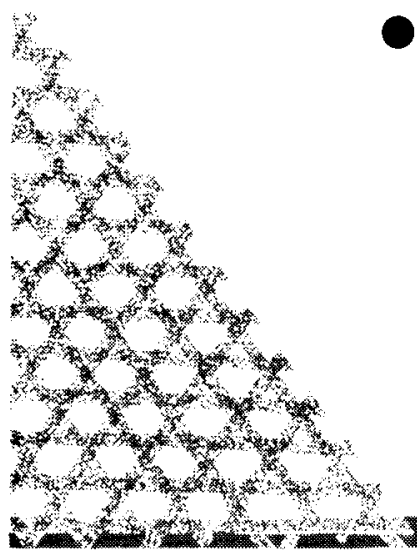

Tele-Education via Satellite Internet /

Hidetoshi KIMURA and Seiichi KUROKAWA

Key words: satellite communication, multimedia, internet, tele-education

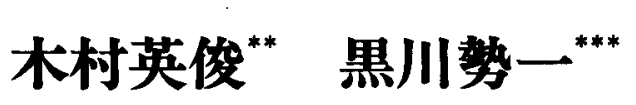

,

1. はじめに

マルチメディフの教育応用が近年盛んに試みられてい

る. 教育にインターネットを利用しよらとする動きが始ま り，また，複数の大学で学際的な交换授業を行らスペース コラボレーション等, 新たな可能性を見い出すような試み が行われている. マルチメディアネットワークが教育に対 して貢献できることは，一言で言えば時間と空間の超越に あるが，その利用方法について確立したとは言えず，まだ 検討の緒についた段階と言党る.

学校法人東海大学と NTT は教育ならびにネットワーク やマルチメディアに関する両者のノウハウを融合させて新 たな発展を生むことを目的に，衛星マルチメディア利用共 同プロジェクトを1995年 5 月に創設した.

1996 年 6 月より全国 15 の大学キャンパスをネットワー クで結び遠隔教育に関する実験を開始した。そその後，付属 高校，学生宅，医学部発信の遠隔医療研修実験に参加する 医療関係者宅をネットワークに加之，遠隔講義と在宅学習 へのマルチメディア通信の活用をねらった実験を行ってい $ろ^{1)}$.

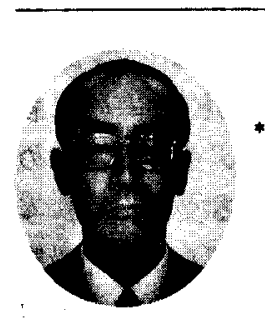

* 原稿受付 平成 9 年 10 月 27 日

* 学校法人東海大学総合科学技㧓研究所（東京都 涉谷区富ヶ谷 2-28-4)

*** 日本奄信電話(株)技術部 (東京都新宿区西新宿 $3-19-2)$

木村英俊

1961 年東北大学工学部通信工学科卒, 1966 年 同大学院博士課程传了, 工学博士. 同年 NTT 入社. ディシタル层送, ディシタル通信網, 光 通信等の研究開発に従事. 1991 年より東海大 学開発技術研究所教授. 1997 年上り現聵. 通信網の利用面からみた性能評 価，特にサービス/ネットワーク品質の研究に従事

奥川雪-

1975 年東京大学工学部電気電子工学科卒, 1977 年同大学院管士踝程了. 同年 NTT 入社. 地上無線通信システム, 衙星通信システム等の実用化な らびに技街企画等の羓狢徉事
以下に，本実験システムの概要，およびこれまでの実験 から得られた評価について述べる.

\section{2. システム柡成}

マルチメディアの利用用途は教育に限らず無数に存在す る. 応用分野ごとにネットワークシステムを構筑すること は効率的でない，システムのうち，共通化できる部分と応 用分野ごとの付加機能とを区分することによって，システ ムの応用範囲を広げることができる，そこで，通信回線， サーバ, アプリケーション等のネットワークシステムを構 成する要素を分類，整理して，图 1 亿示す階層化構造とな るよう構成した. この構造は, アプリケーション, システ ム，ネットワークの3つのレイヤから構成されて，それぞ れが独立して機能追加，拡充ができるようになっている2゙.

\section{1 ネットワークレイヤの椿成}

情報のディジタル化により，どのような種類/形態の情 報であれ同一のりのとして报らことができる。このため 様々なコンテンッやフプリケーションがーつのネットワー クを共有することにより，新たなサービスが生まれる可能 性が高まり，またデータの流通（伝送）コストや装置コス トの低隇が容易になる.

インターネットは，むさにこのよ5な流れを象徵して発 展を紿けているよらに見光るが，主にアクセス回線の細さ に䌗られて，持てる可能性を充分に発揮できていない，

ここで，マルチメディア通信サービスの特徽について整 理すると以下のよらになる.

（1）情報の種類により多様な伝送速度：例えぱ，映像 と文字情報では必要带域は 3 けた以上異なる.

（2）フンバランスな通信：例えばWWWなどデータ ベースにアクセスする場合に，ニーザから情報提 


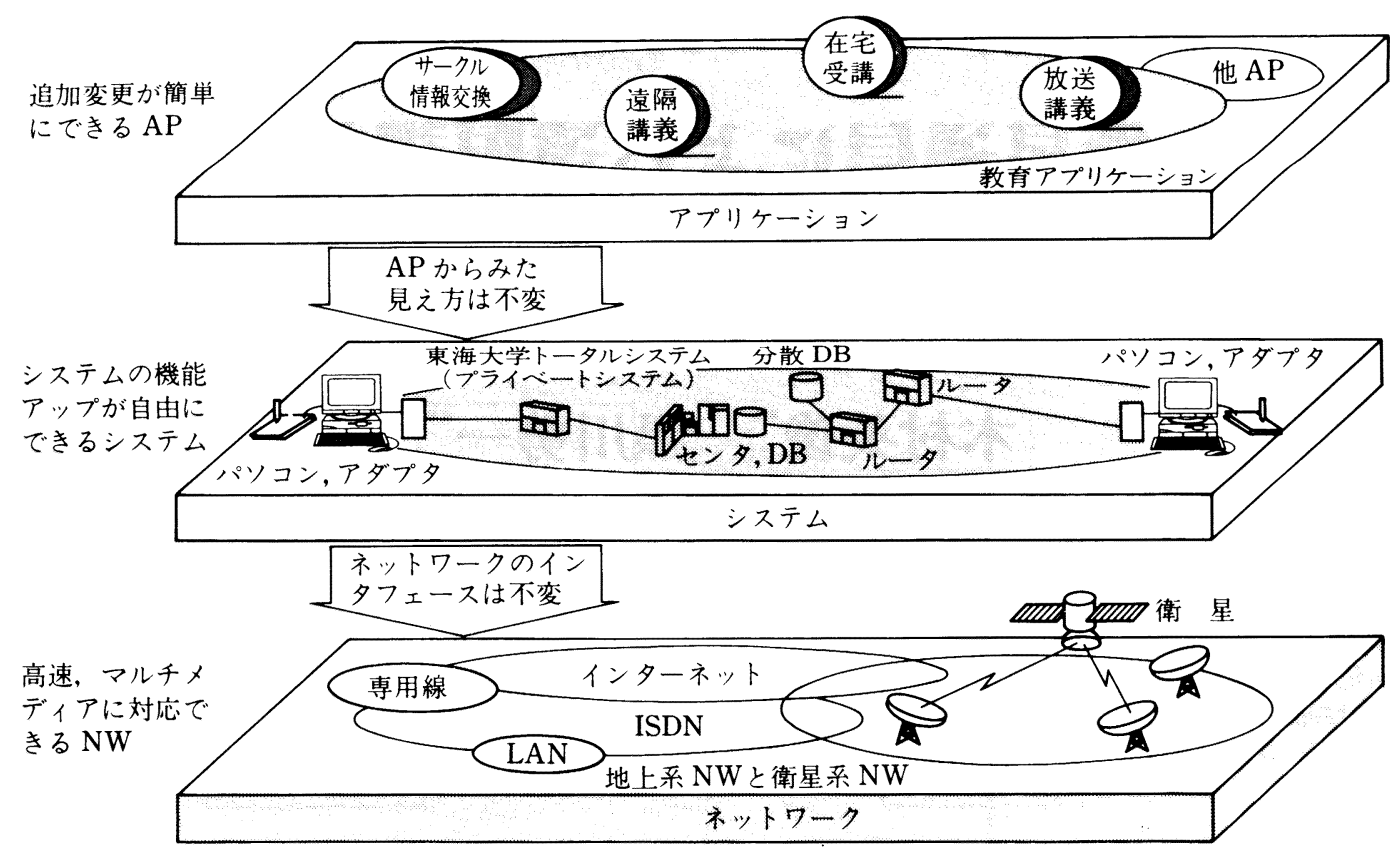

図 1 ネットワークシステム構造の概念

供者（IP：Information Provider）のサーバに対 しデータ送信要求のような短い信号を発信するの に対し，IPからユーザへは，大量のデータが送ら れてくるアンバランスな通信が多い.

（3）多様な接続形態：接続形態は 1 対 1,1 対 $n, m$ 対 $n$ 等多様化した接続形態で通信する.

マルチメディア通信サービスに必要な広帯域ネットワー クを構築するためには, 全家庭への普及に, まだ時間がか かりそうなFTTH (Fiber to the home) を待つまですな く, 衛星通信の利用が現実的な手段として有望である.

これまで, 衛星回線を利用するには, 大型のアンテナ や，高価な送受信装置が必要であったために，一般には利 用できにくい面があった．しかし，先にも述べたように， 双方向ともに広帯域の回線を必要とするアプリケーション はむしろ少ない，そこで，東海大・NTT 共同プロジェク トでは，個々のユーザ端末から衛星への送信機能を削除 し, 情報受信のみに高速な衛星回線を利用し, ユーザから の発信を地上回線で行ら非対称なネットワーク構成として 各ユーザ端末を小型化，低廉化させた。

衛星への送信は一つの中継器に対して 1 か所の送信基地 から行い, 畳み込みとリードソロモンの連接符号による誤 り訂正で, 極めて信頼性が高いデータ伝送を行っている3).

衛星回線上の通信プロトコルは, ATM ルル多重化方式 を採用した ${ }^{4)}$. ATM は 1 対 1 通信と 1 対多通信双方への 対応，広帯域伝送および様々な伝送速度を混在して扱らこ とが可能など，マルチメディア通信への適合性が高い.

ネットワーク構成を図 2 に示す。また, 衛星回線の主要 諸元を表 1 に示す.

衛星送信局は複数の遠隔講義スタジオ, データベース サーバなどIP からの情報を ATM セル化して衛星回線へ
送信する.

ユーザ側の装置は開口径 $50 \mathrm{~cm}$ 程度の小型アンテナ, ディジタル衛星放送チューナ, 受信アダプタ, PC で構成 される. 受信アダプタは, 受信した ATM セルから自局あ てのパケットを再生し，モデムやTAを介して接続した 地上回線と合わせて，ユーザ端末に対して双方向のネット ワークを提供する役割を果たす。受信アダプタとユーザ端 末のインタフェースは，汎用性を考虑してEtherを用い る. また，適宜に設けられたアクセスポイントに地上回線 経由で PPPで接続する ${ }^{5)}$. 図 3 にューザ側装置構成例を 示す.

\section{2 アス゚リケーションレイヤ}

教育への対応は主にこのアプリケーションレイヤで行っ ている. 用意したアプリケーションはリアルタイムの遠隔 講義に対応したものと，オンデマンドで教材にアクセスす る蓄積型教材利用の 2 種類に大別される.

\section{1）遠隔講義}

共同実験で用いた遠隔講義用アプリケーションは，対面 学習と同等の双方向性を確保することを目的に, NTTが 社内研修向けに開発したアプリケーションである $\mathrm{STARTs}^{6}{ }^{6}$ を用いた。講義は，主に代々木校舎内の講義 室から発信され，各キャンパスで受信する．生徒は汎用の $\mathrm{PC}$ 上で講師の操作によって送られてくる文字, 図, 写 真，動画などのマルチメディア教材を見ながら講義を受講 する．教材をNTSC 信号で送信するような従来型の遠隔 講義と異なり，コンピュータデータとして教材を送るた め, 特に, 図や写真は, 高い解像度のまま PC 画面に表示 することができるらえ，データ容量が小さくできるため， ネットワークへの負荷も少ない. このように, PCの利用 


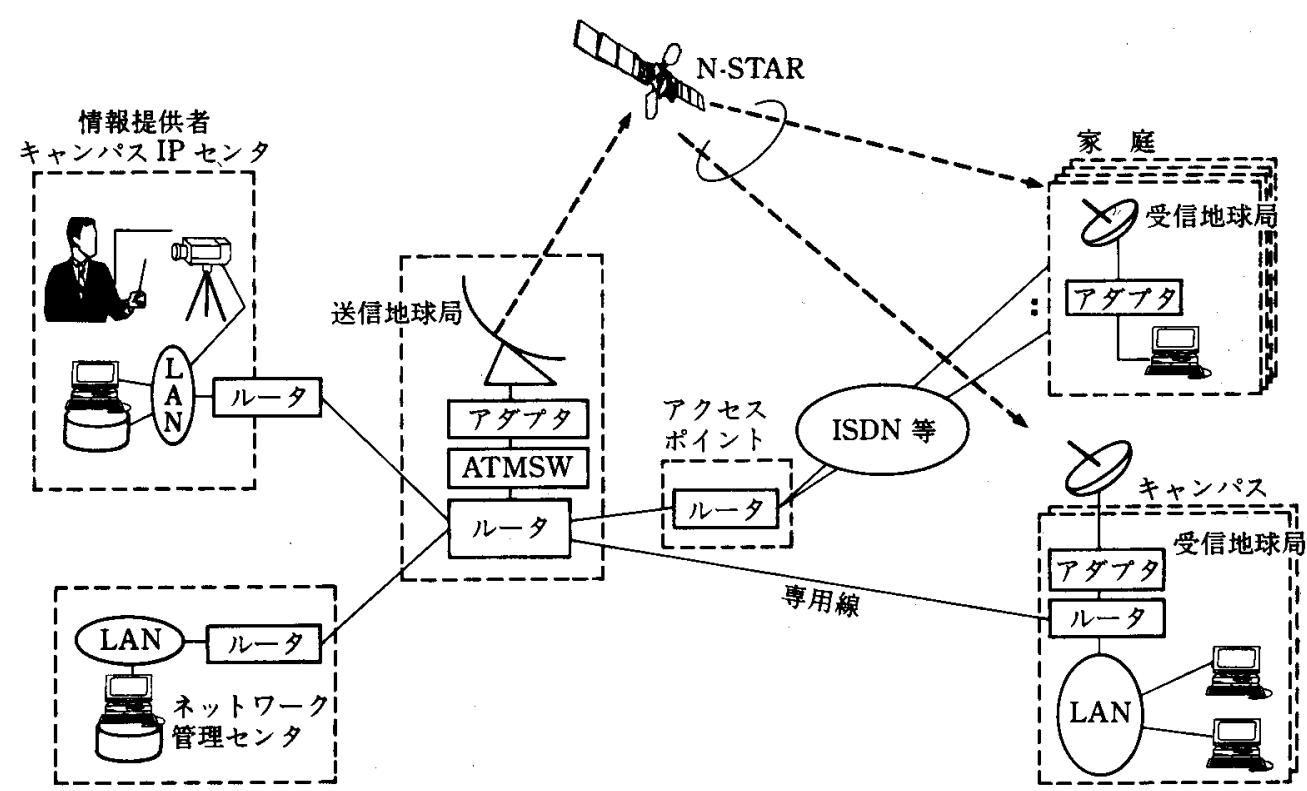

图 2 ネットワーク構成

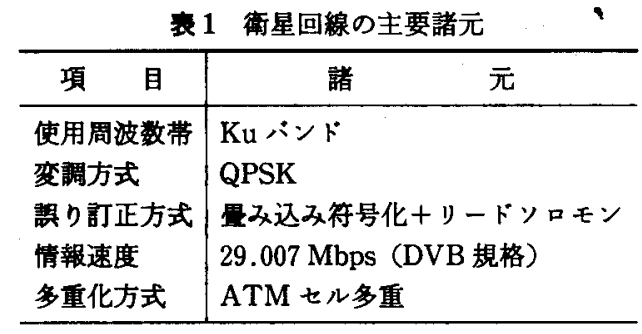

で，教材環境は従来型のどの形態よりる優れたるのが経済 的に提供できる. 教材には主にフリップと呼ぶ静止画教材 を使い, 補助教材として, 動画, 写真, 音声を必要に応し て併用する.

講義に用いる教材はあらかじめデータベースに登録して 括き, 講師の操作によってデータベースから衛星回線を通 して, 受講生の端末に配信される.このデータはネット ワーク同報で送られ，街星回線での誤 りはきわめて低く抑えられているの で, 受講生端末が多くても再送の增加 などでネットワークやサーバの負荷が 增えることは汪とんど無い。

学生端末の表示例を图 4 亿示す. 講 師の映像は PC 画面隅化小さなウィン ドゥで表示している.このよ5に1台 のディスブレイの中に必要な情報をす べて表示することで, 受講生の余分な 視線の動きが無くなり，集中して授業 を受けることができる.

講師はタッチベンによる描画機能を 使って、フリップ上へ板書をするよう に線画や文字を加えて説明を補いなが ら，教室での授業さながらの臨場感を 持って授業を進めることができる。

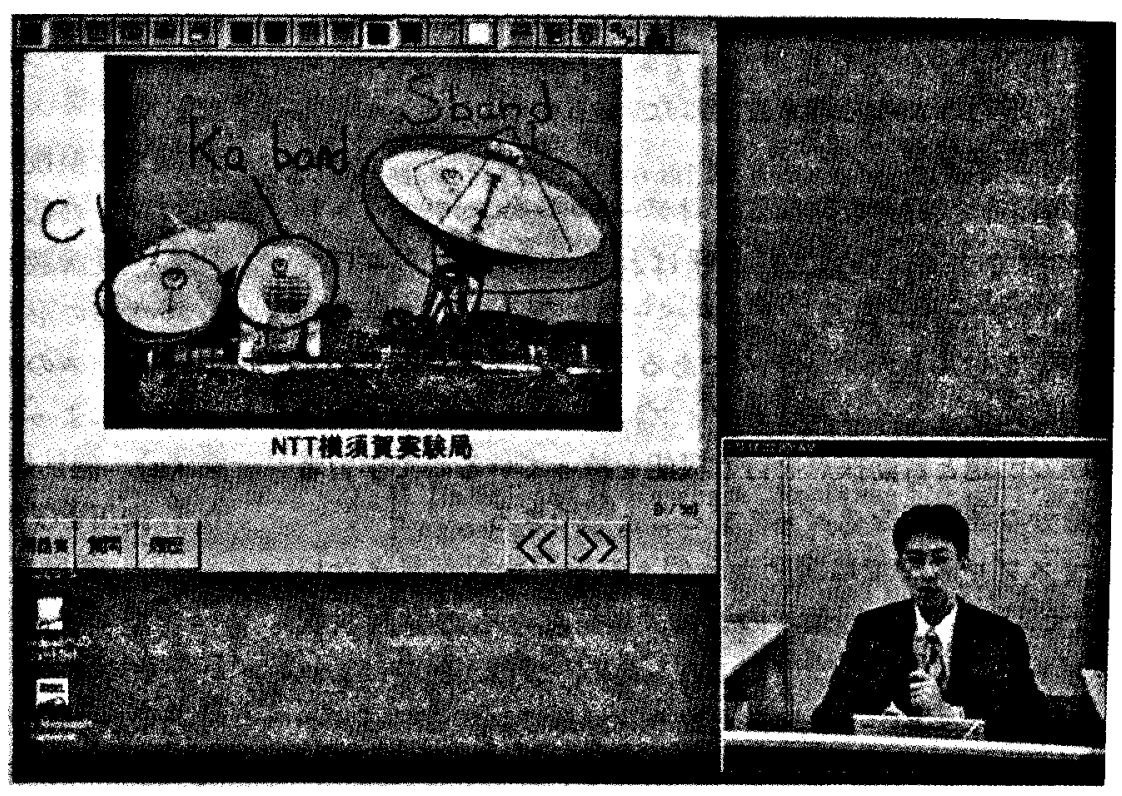

图 4 学生端末表示例 
表 2 講師側からの情報

\begin{tabular}{l|l|l}
\hline \multicolumn{1}{c|}{ 項 } & \multicolumn{1}{|c|}{ 内 容 } & \multicolumn{1}{|c}{ 備 } \\
\hline フリップ 考 \\
補助教材 & 電子 OHP & マーキング可 \\
& 写 真 & BMP 形式 \\
& 動 画 & MPEG 形式 \\
& 音 声 & WAV 形式 \\
講師映像/音声 & 映像/音声 & MPEG またはH. 261 \\
テスト/アンヶート & 選択式問題 & 集計結果グラフ表示 \\
実行形式ファイル & 受講生端末で自動起動 & ○○.exe \\
\hline
\end{tabular}

表 3 受講生側からの情報

\begin{tabular}{l|l|ll}
\hline \multicolumn{1}{c|}{ 項 } & \multicolumn{1}{|c|}{ 内 } & 容 & 備 \\
\hline 出席登録 & 受講場所, 学籍番号, 氏名入力 & \\
質 問 & $\begin{array}{l}\text { テキスト入力 } \\
\text { マーキング }\end{array}$ & 線画/文字 64 文字 \\
アンケート回答 & 数字入力 & \\
テスト回答 & 数字入力 & 選択数 : 5 \\
\hline
\end{tabular}

受講生は質問があるときには，随時キーボード入力によ り講師にその内容を伝えることができる、受講端末では講 師端末と同様な描画機能を持っており，講師側の操作によ り特定の受講生の描画を講師端末に表示させたり, 全員に 配信することができる.この機能により図形を併用した質 問をしたり，“板書”による発表をさせる，などの双方向 の機能が利用できる. 講師は出席の確認や演習問題やアン ケートの出題ができるばかりでなく，集計して統計を取る ことができる.

これらの機能を表 2,3 に示す.

映像は, フル動画 (MPEG 1) と準動画 (Software Vision $)^{7)}$ の 2 通りの方法を用いた。 これらの異なるシス テム構成は，主にキャンパスや受講側の事情によって使い 分けた.この点については後節で説明する.

フル動画システムはSTARTsの一部として開発したも ので, MPEG デューダボードを搭載した PCでのみ表示 が可能である. これに対し，準動画はソフトウェアでデ コードを行らため，端末を選ばない.

2) 在宅学習

学習者は，好きな時間に教材データベースヘアクセスし て学習できる. CALATと呼ばれるこのシステムは, WWW サーバ上の教材データベースに個人対応の学習管 理機能を付加したシステムである ${ }^{8)}$. 学習は個人の理解す る速度に従ってインタラクティブに進める. もちろん演習 問題の出題と自動採点を行ら機能を持っているので学習者 は自分の理解度をチェックすることができる.

マスプロ教育では講師から個々の学習状況が見えない が, CALAT では, 個々の進捗, 理解度などの学習状況 データをログとして管理しているため, 講師が随時にこれ を確認することができ, 指導法や教材へのフィードバック が行える. このようなことは, 教材や学生の学習状況デー タをサーバ上に集中させることから可能になってくること
で，CD-ROM などで配布する教材には，真似のできない ことである.

\section{3 システムレイヤ}

サーバやクライアント端末の配置などアプリケーション やキャンパスの事情に密接にかかわってくるものについて 述べる.

\section{1）講義スタジオ}

共同プロジェクトにおいては東海大学代々木校舎に遠隔 講義スタジオを設け，スタジオ内に遠隔講義用の教材サー バ，動画サーバ，蓄積教材サーバ，メールサーバなど情報 発信の核となる機能を集中させた。代々木校舎と衛星送信 局との間は地上の高速ディジタル専用線で接続した.

共同プロジェクトでは，距離を超越して都市や地方の区 別無く講義を受講できるシステム作りを行った．同様に， 講義発信も距離を超越できなくては，片手落ちであるとの 強い示唆に基づき, 代々木校舎以外の場所からも講義発信 が行えるよらにした ${ }^{9)}$. 代々木校舎以外の講義室では, STARTs の講師用操作端末であるPCとSoftware Vision 用の H. 261 映像エンコーダを講義スタジオから切 り出して, INS 64 を 3 本束ねた地上回線と衛星回線で 接続することとした. この構成で簡易型スタジオを東海大 学病院内に作り，医学部から開業医に向けた遠隔医療研修 を行っている.その他のキャンパスには，エンコーダと簡 易なルータを持ち込み，現地の INS 64 回線を利用した臨 時の遠隔地スタジオからの講義を実施した。広帯域回線が 必要なリアルタイム MPEG 映像以外は遠隔地スタジオか らでも，代々木スタジオからの講義発信とほぼ同等の操作 性で講義が行えることを確かめた。衛星送信設備や遠隔講 義用のサーバを全国で共有して使らことができることは， 東海大学のように全国にキャンパスが遍在する場合でも低 コストで全国のキャンパスから講義発信が行えることを意 味する．例えば，各キャンパス個別に衛星送信設備と教材 サーバを持つ場合に比較して，コストは $1 / 10 〜 1 / 20$ にな る，スペースコラボレーションで行われているように，大 学間で交換授業を行うことが将来本格化すれば，このよう なコストの低さは重要になってくる.

\section{2) 受講教室}

受講室の形態には次の 2 種類がある. 形態の選択は, 各 キャンパスの端末保有状況や教室内 LAN などの状況, 利 用目的によって行われている.

（a）個別端末型：受信機からルータを介して複数の受 講用 PC を接続し, 各学生が使用する.

（b）視聴覚室型：1 台の受信機に受講用 PC を接続し, 全学生で受講する.人数が多い場合は, プロジェクタ でスクリーンに投影する.

また, 一部のキャンパスにはテレビ会議システムを設置 して講義室から教室の模様や，学生の反応をモニタしなが ら授業を行らことが可能になっている. 


\section{3. 評価と運用の実際}

これまでに, 約 50 回の遠隔講義と 20 編の自習用教材を 作成し運用している. その中での評価と，これを受けての 改良について述べる.

\section{1）受講側の評価}

学生からのアンケートを分析すると, 第一に音声, 第二 に教材の表示品質が重要であることが分かった。 ここで, 2 番目に重要とされる教材はPCで作成した品質のまま受 講端末に送り届けられるので，黒板や OHP で投影像を見 る教室よりもむしろ良好な品質であると高い評価を得た。 音声/映像の品質も準動画であるにもかかわらず比較的評 価が高く, 約 9 割が満足あるいは, 汪満足といら結果が 得られた.ただ, 音声の品質評価は教室によって異なる傾 向にあり, 教室の音響設備の品質も重要な要素になること が分かった ${ }^{10)}$.

その他, 定量評価ではないが，アンケートや質問など双 方向機能への関心が高く,「同時に受講している各地の学 生の意見が聞けて良かった」といった感想が多く見られ た.

\section{2） 講師側の評価}

（a）遠隔地からの講義発信：遠隔地から ISDN 回線を 用いる遠隔地発信講義形態を加えた後は，手軽に全国 に向けた遠隔講義が行えること, 使い勝手, 機能とも 実用に供しらるとの評価を得た. インターネットによ りどこからでも世界に向けた情報発信ができることか ら，遠隔講義といえども今後は，これは基本機能と位 置づけられるようになるであろう.

（b）従来型講義の実施：STARTsによる遠隔講義で は教材の電子ファイルがあらかじめ必要であるなど, 従来型講義とは準備内容, 講義スタイルとも異なって くることから, 遠隔講義の試行を負担に感じる講師が 多いことは否めない. そこで, 従来に近いスタイルで 講義を行えるようにTV放送スタイルの授業も行っ た.この方法では, 講師カメラや教材を映す書画カメ ラなとからの NTSC 信号を 1.5 Mbps の MPEG 1 圧 縮をして送るもので，片方向の授業になる，ただし， 双方向性を補らためにコーラスライン（NTTが提供 する多地点電話会議サービス）を併用した. 授業のス タイルや事前準備が通常講義に近いなど，負担が少な いことから講師からの評判は良かった。ただこの形 式では高い解像度の教材を利用できないなどのデメ リットが逆に浮き彫りになった.

（c）教材の作成：マルチメディアの利用にかかわらず, コンテンツが最も重要であることは言うまでもない. STARTsを用いた遠隔講義とこれまでの講義を比較 して，基本的な部分では，大きく変わることは考光難 い.しかし, 遠隔講義では, 板書を主体としていた従
来型の授業から, 準備内容, 講義手法に多少の変革が 必要である. 特に講師にPCで作成した図面などの ディジタルコンテンッの蓄積がない場合には, 教材作 成といらハードルが存在することは否めない.こうし た問題の解決には, システム上で教材作成労力削減の ための方策を講じて行くばかりでなく，運用を支援す る体制が必要であろう。

\section{4. ま と め}

本報告では, 遠隔教育において教育効果を高める方策と してのマルチメディア利用を研究する東海大学・NTT 衛 星利用マルチメディア共同プロジェクト実験について述べ た.

マルチメディア利用は，PC やゲーム機の普及とともに 日常のものとなりつつあるが, 教育への利用といら面で は，まだまだ開拓途上の分野といえる，一方，技術の高度 化が専門教育の細分化を進め, 社会のニーズから生涯教育 が行われるよらになった現在, 限られた教育側のリソース を生かすために遠隔教育もまた必要なものになりつつあ る. 共同プロジェクトでは, 一つのプロトタイプとして構 築したシステムの上で高等教育向けのシステムを一つの ターゲットとして様々な試行を行っている. 今後, この結 果をフィードバックしながら, システムを実用レベルに仕 上げるために取り組んでいく.

\section{謝辞}

共同プロジェクト推進に尽力いただいている，学校法人 東海大学, NTT の関係各位に深謝いたします.

\section{参 考 文 献}

1）水野秀樹ほか：東海大学共同プロジェクト, 電気通信, 60 (1997.5) 605.

2）土井英司ほか：マルチメディア双方向衛星通信システム, 1996 信学春大, SB 3-4, (1996).

3）大津茂雄, 川添雄彦, 亀澤祐一, 滝沢良二, 滝澤 暢：マル チメディア衛星通信方式の信号伝送特性, 信学技報 SAT 96-92, (1996) 73 .

4) M. Nakayama, K. Araki, M. Kobayashi and H. Nakashima: A Satellite Communication System using ATM Multiplex Scheme for Interactive Multimedia Networks, 48th IAF, IAF-97-M. 2. 10, Oct 6-10, $97 /$ Turin, Italy.

5）化平勝利ほか：同報インタラクティブ衛星通信方式に打ける 衛星回線接続アダプタの構成, 1996 信学春大, B-268, (1996).

6）マルチメディア技術を活用した新しい衛星遠隔研修システム (新STARTs) の開発について, NTT Business, No.564, (Mar. 1997).

7) H. Jinzenji and H. Kasahara : Real-time Stream Transport Protocol and Software Vision, Proc. IPSJ Symp., 96, 2, (1996) 9.

8) K. Nakabayashi et al. : A Distributed Intelligent CAI Systems on the World-Wide Web, Proc. ICCE 95, (Dec. 1995) 214.

9）伊津信之介ほか：衛星利用遠隔教育の可能性，平成 9 年度情 報処理教育研究集会論文集, (1997) 259.

10）木村英俊ほか：衛星マルチメディア通信を利用した教育応用 システムの構成と品質に関する検討, 電子情報通信学会論文 誌, J 80-B-I, 6 (1996) 355. 